\begin{tabular}{|c|c|c|}
\hline 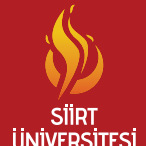 & $\begin{array}{c}\text { Türkiye Tarımsal Araştırmalar Dergisi } \\
\text { dergipark.gov.tr/tutad }\end{array}$ & $\begin{array}{l}\text { Turk J Agric Res } \\
\text { 2018, 5(3): 201-208 } \\
\text { ○ TÜTAD } \\
\text { ISSN: 2148-2306 } \\
\text { e-ISSN: 2528-858X }\end{array}$ \\
\hline $\begin{array}{l}\text { UNNIVERSITESI } \\
\text { Bilimin Dsüqumda }\end{array}$ & Araştırma Makalesi / Research Article & $\begin{array}{l}\text { e-ISSN: } 2528-858 \mathrm{X} \\
\text { doi: 10.19159/tutad.397285 }\end{array}$ \\
\hline
\end{tabular}

\title{
İyon-Seçici Elektrotlar Kullanılarak Samsun-Çarşamba Bölgesindeki Topraklarda Kalsiyum ve Magnezyum Tayini
}

\author{
Adem ASAN" \\ Ondokuz Mayls Üniversitesi, Fen Edebiyat Fakültesi, Kimya Bölümü, Samsun, TÜRKIYY
}

\begin{tabular}{l}
\hline Geliş Tarihi/Received: 21.02.2018 $\quad$ Kabul Tarihi/Accepted: 10.08 .2018 \\
\hline ORCID ID \\
(Dorcid.org/0000-0002-0282-3874 \\
"Sorumlu Yazar/Corresponding Author: aasan@omu.edu.tr
\end{tabular}

Öz: Bu çalışmada, toprakta bulunan kalsiyum $\left(\mathrm{Ca}^{2+}\right)$ ve magnezyum $\left(\mathrm{Mg}^{2+}\right)$ iyon derişimlerinin belirlenmesi amaçlanmıştır. $\mathrm{Bu}$ amaçla, ticari olarak satın alınan iyonofor maddeler ile $\mathrm{Ca}^{2+}$ ve $\mathrm{Mg}^{2+}$-seçici mikro boyutta potansiyometrik PVC-membran elektrotlar geliştirilmiştir. Hazırlanan $\mathrm{Ca}^{2+}$ ve $\mathrm{Mg}^{2+}$-seçici elektrotların potansiyometrik performans karakteristikleri belirlenmiş ve ölçümlerde ana iyon çözeltisine karşı her 10 kat konsantrasyon değişimi için sırasıyla ortalama 23.5 ve 27.6 $\mathrm{mV}$ potansiyel farkı gözlenmiştir. Elektrotlar, $10^{-1}-10^{-5} \mathrm{~mol} \mathrm{~L}^{-1}$ derişim aralığında ana iyon çözeltisine karsı doğrusal davranış sergilediği, alkali ve toprak alkali metal iyonlarının yanında ana iyona karşı oldukça seçici olduğu belirlenmiştir. Laboratuvarda hazırlanan potansiyometrik PVC-membran iyon-seçici elektrotlar kullanılarak toprak numunelerindeki $\mathrm{Ca}^{2+} \mathrm{ve}$ $\mathrm{Mg}^{2+}$ analizleri yapılmıştır. Geliştirilen yönteminin doğruluğu Atomik Absorpsiyon Spektroskopisi (AAS) tekniği kullanılarak analiz test edilmiş ve sonuçların birbiri ile uyum içinde olduğu görülmüştür. Elde edilen sonuçlar, geliştirilen $\mathrm{Ca}^{2+}$ ve $\mathrm{Mg}^{2+}-$ seçici mikro boyutta potansiyometrik PVC-membran elektrotlar ile toprak numunelerindeki bu iyonların tayininde rutin olarak kullanılabileceğini göstermektedir.

Anahtar Kelimeler: İyon-seçici PVC-membran elektrot, potansiyometri, toprak, kalsiyum, magnezyum

\section{Determination of Calcium and Magnesium in Soils of Samsun-Çarșamba Region by Using Ion-Selective Electrodes}

\begin{abstract}
In this study, potentiometric PVC-membrane electrodes were developed with calcium $\left(\mathrm{Ca}^{2+}\right)$ and magnesium $\left(\mathrm{Mg}^{2+}\right)$-selective micro-dimensions with commercially purchased ionophore to determine $\mathrm{Ca}^{2+}$ and $\mathrm{Mg}^{2+}$ ion concentrations in the soil. The potentiometric performance characteristics of the prepared $\mathrm{Ca}^{2+}$ and $\mathrm{Mg}^{2+}$-electrodes were determined and the average potential difference of 23.5 and $27.6 \mathrm{mV}$ was observed for each 10 fold change in concentration versus the parent ion solution in the measurements. The electrodes were found to exhibit linear behavior versus the parent ion solution at a concentration range of $10^{-1}-10^{-5} \mathrm{~mol} \mathrm{~L}^{-1}$ and to be highly selective to the parent ion besides the alkali and alkaline earth metal ions. $\mathrm{Ca}^{2+}$ and $\mathrm{Mg}^{2+}$ analyzes of soil samples were performed using potentiometric PVC-membrane ion-selective electrodes prepared in the laboratory. The accuracy of the proposed assay was tested using the AAS technique and the results were found to be in agreement with each other. The results show that the potentiometric PVC-membrane electrodes in the developed $\mathrm{Ca}^{2+}$ and $\mathrm{Mg}^{2+}$-selective micro-dimensions can be used routinely in the determination of these ions in soil samples.
\end{abstract}

Keywords: Ion-selective PVC-membrane electrode, potentiometry, soil, calcium, magnesium

\section{Giriş}

Toprak, bitkilerin köklerini geliştirdiği ve yaşamalarını devam ettirmek için gerekli su ve besin maddelerini aldığı ortamdır. Toprağın fiziksel ve kimyasal özellikleri, organik madde miktarı ve organik maddenin durumu, toprakta yaşayan canlılar, toprak içindeki ayrışma ve yeniden oluşum 
olayları dinamik ve kendi içinde dengeli bir ekolojik sistem oluşturmaktadır. $\mathrm{Bu}$ dinamik sistemdeki bitki besin maddelerinin bulunuşunun şekli ve bitkiler tarafından alınabilir durumdaki miktarları çok önemlidir. Diğer bir deyimle toprağın bitki besin maddesi kapasitesi toprağın verimliliğinin önemli ölçülerinden birisidir (Kantarc1, 1997).

Tarımsal üretimin temeli toprak olduğu için, tarımda istenilen miktar ve kalitede ürünün elde edilmesinin birinci şartı toprakların verimlilik düzeylerinin arttırılmasıdır. Toprak verimliliğini arttırmada en önemli faktörlerden birisi ise bitki besin elementleridir. Besin elementleri bitki gelişiminin önemli bir parçası olup bir veya daha fazlasının eksikliği verimi ve kaliteyi olumsuz yönde etkilemektedir. $\mathrm{Bu}$ besin elementlerinin başında kalsiyum (Ca) ve magnezyum ( $\mathrm{Mg}$ ) gelmektedir (Koc ve Szymczyk, 2003).

Diğer taraftan topraktaki bu elementlerin birbirine göre oranları da bitkinin bu elementleri almasını etkilemektedir (Karaman ve ark., 1999). $\mathrm{Bu}$ etki, bütün bitkileri aynı oranda etkilememektedir (Güzel ve ark., 2004).

Genellikle toprakta bitki ihtiyacını karşılamaya yetecek düzeyde kalsiyum bulunur. Özellikle kurak ve yarı kurak bölge topraklarında yıkanma olmadığ için kalsiyumun topraktaki derişimi yüksektir (Kabrick ve ark., 2011).

Kireçli kurak bölge topraklarında Ca diğer bazı besin elementlerinin, özellikle mikro elementlerin alınmasında antagonistik etki (elementlerin birbirinin alımını engellemeleri) olușturacak kadar fazla bulunabilmektedir. $\mathrm{Bu}$ nedenle bitkilerin $\mathrm{Ca}$ alımında ortaya çıkan azalmalar Ca noksanlığına bağlı problemleri de beraberinde getirir. Toprağın ideal toprak haline dönüştürme işlemine toprak 1slahı denir. Bitki beslenmesi için ideal toprakta verim maksimum olur. Dolayısıyla birim maliyeti düşer. Yapılan işten de en fazla kar elde edilir. $\mathrm{Bu}$ nedenle toprak ıslahı çok önemlidir. Bir toprağın nasıl 1slah edileceği ancak toprağın analizi yapılarak karar verilir. Bu nedenle toprak analizi büyük önem taşır (Anonim, 2018).

Toprağın fiziksel özellikleri, kimyasal bileşenleri ve makro-mikro besin element içerikleri, pH's1 toprak analizi ile belirlenir. İdeal toprak değerlerinden sapmalar tespit edilerek bu değerlerin normal değere nasıl çevrilebileceğine karar verilir. Bitki besin elementleri bitkinin yaşamını sürdürebilmesi için gereksinim duyduğu başlıca maddelerdir. $\mathrm{Bu}$ maddelerden kalsiyum ve magnezyum ikincil besin grubuna girer (Karaman ve ark., 1999).
Topraktaki inorganik katyonların aynı anda doğru, hassas ve hızlı tayinleri tek basamakta iyon kromatografik yöntemler kullanılarak yapılabilmektedir (Pavel, 2001). Ancak, iyon kromatografide, iletkenlik detektörünün sinırlı sayıda hareketli faz sistemleri ile uygulanabilmesi "suppresor" kolon kullanım zorunluluğu ve bunun ekonomik olmayışı, ayrıca yaygın olarak kullanılan iletkenlik (kondüktometrik) detektörün bazı anyon ve katyonların tayininde başarılı olmaması, araştırmacıları maliyeti düşük yeni tayin yöntemleri üzerine yoğunlaştırmıștır (Watanabe ve ark., 1991; Sang ve ark., 1993; Işıldak ve Asan, 1999). Toprakta kalsiyum ve magnezyum tayini çeşitli yöntemler kullanılarak yapılmaktadır. Bu yöntemlerden en yaygın kullanılanı Atomik Absorpsiyon Spektroskopisi yöntemidir (Alexandra ve ark., 1995; Lopez ve ark., 1996; Zikri ve Julian, 1999; Zhang ve ark., 2012).

Atomik Absorpsiyon Spektroskopisi (AAS) yöntemi, pahalı ve uygulaması zaman alıcı bir yöntemdir. $\mathrm{Bu}$ nedenle, bu iyonların tayini için alternatif analiz yöntemlerine ihtiyaç vardır. Potansiyometrik yönteme dayanan iyon-seçici elektrotlar son y1llarda önem kazanmış, günümüzde geniş bir kullanım alanına sahip ve iyi bilinen alternatif bir yöntemdir (Captian-Vallvey ve ark., 2003).

$\mathrm{Bu}$ çalışmada; Samsun için önemli tarım alanlarından biri olan Çarşamba ilçesindeki topraklarda kalsiyum ve magnezyum derişimini belirlemek için yeni bir tayin yöntemi geliştirilmiştir.

\section{Materyal ve Yöntem}

\subsection{Kullanılan kimyasallar}

Çalışmada, iyon-seçici elektrotları hazırlamak için; tetrahidrofuran (THF), yüksek molekül ağırlıklı polivinilklorür (PVC), onitrofeniloktileter (NPOE), [12, (4-etil fenil) dodesil] 2 nitrofenileter (ETH 8045), potasyumtetrakis (p-kloro) fenilborat (KTpClPB), grafit ve iyonoforlar N,NDicyclohexyl-N',N'-dioctadecyl-3-

oxapentanamide, kalsiyum iyonofor $\left(\mathrm{C}_{52} \mathrm{H}_{100} \mathrm{~N}_{2} \mathrm{O}_{3}\right)$ ve 1,3,5-Tris[10-(1-adamantyl)-7,9-dioxo-6,10diazaundecyl]benzene, magnezyum iyonofor $\left(\mathrm{C}_{63} \mathrm{H}_{96} \mathrm{~N}_{6} \mathrm{O}_{6}\right)$ kullanılmış ve bu maddeler Fluka (Bucks, Switzerland) firmasından, epoksi reçinesi (Ultrapur SU 2227 Victor (Italy) firmasından, sertleştirici (Desmodur RFE) ve elektrot hazırlamada kullanılan diğer tuzlar ise Merck (Darmstadt, Germany) firmasindan temin edilmiștir. 


\subsection{Standart çözeltilerin hazırlanması}

Çalışmada hazırlanan elektrotların potansiyometrik performanslarının belirlenmesi için standart katyon çözeltileri kullanılmıştır. Standart stok çözeltiler, katyonların nitrat tuzlarından hazırlanmıştır. Bütün standart stok çözeltileri deiyonize su ile analitik saflıktaki maddelerden $0.1 \mathrm{M}$ olacak şekilde hazırlanarak istenilen derişimlere seyreltilmiştir. Hazırlanan stok çözeltiler buzdolabında saklanmıştır.

\subsection{Potansiyometrik iyon-seçici elektrotların hazırlanması}

İyon-seçici elektrotları hazırlamadan önce, katıkontak karışımı bir bakır tel üzerine kaplanmış ve daha sonra oda sıcaklığında kuruyan bu katı-kontak yüzeyine, hazırlanan PVC-membran kokteylleri kaplanmıştır. Katı-kontak karışımı hazırlamak için; ağırlıkça \% 50 grafit, \% 35 epoksi reçinesi (Ultrapur SU 2227) ve \% 15 Sertleştirici (Desmadur RFE) tartılarak THF çözücüsü içerisinde çözülmüş ve homojen bir karışım elde edilmiştir. Uygun viskozite sağlandığında, daha önce hazırlanan bakır tel (yaklaşık 0.4-0.5 mm çap ve 5-10 cm uzunlukta) üzerine bu karışım 6-8 defa daldırılarak kaplanmış ve oda sıcaklığında bir gece bekletilerek kullanıma hazır hale getirilmiştir. Şekil 1'de laboratuvarda hazırlanan bir iyon-seçici membran elektrot (bakır tel ucuna membran kaplı) gösterilmektedir.

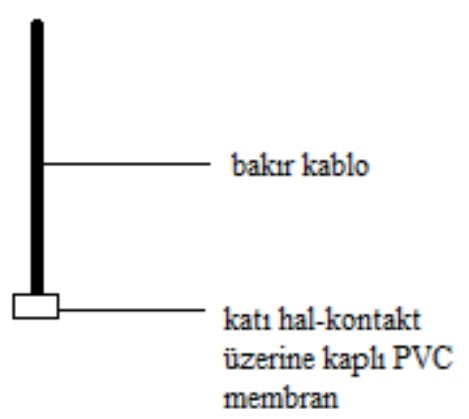

Şekil 1. Laboratuvarda hazırlanan bir mikro boyutta iyon-seçici membran elektrot PVC: Polivinil klorür

\section{4. Çalışma yöntemi}

İyon-seçici elektrotların potansiyometrik karakteristikleri (doğrusal çalışma aralıkları, tayin limitleri, tekrarlanabilirlikleri, seçicilikleri, cevap zamanları ve $\mathrm{pH}$ çalışma aralıkları) durgun ortam ölçümleriyle belirlenmiştir. Elektrotlar ölçüm alınmadığ 1 zamanlarda kuru olarak oda sıcaklığında saklanmış ve her ölçüm alınmadan önce ana iyon çözeltilerinde yarım saat kadar şartlandırılmıştır (doyurulmuştur). Durgun ortamlarda alınan ölçümlerde, elektrotların potansiyel değişimleri, iyon-seçici elektrot ve referans elektrotun 20
mL'lik çözeltiye aynı derinlikte daldırılmasıyla ölçülmüştür. Her ölçümden önce elektrotlar deiyonize su ile yıkanmıştır. Derişimi $10^{-1}-10^{-6} \mathrm{~mol}$ $\mathrm{L}^{-1}$ aralığında olan standart katyon çözeltileri kullanılarak kalibrasyon grafikleri çizilmiş ve bu grafiklerden yararlanılarak toprak numunelerindeki $\mathrm{Ca}^{2+}$ ve $\mathrm{Mg}^{2+}$ tayinleri yapılmıştır.

\section{Bulgular ve Tartışma}

\subsection{Potansiyometrik bulgular}

Bölüm 2.3'te anlatılan yöntemle $\mathrm{Ca}^{2+}$ ve $\mathrm{Mg}^{2+}$ seçici PVC-membran elektrotlar hazırlanmıștır. Her elektrot için aynı hazırlama yöntemi ile çok sayıda farklı kompozisyonlarda elektrotlar hazırlanarak test edilmiştir. Elektrotlardan en iyi performans1 sergileyen kompozisyonları seçilerek potansiyometrik performans karakteristikleri ortaya konulmuş ve optimum membran bileşimleri belirlenmiştir. Tablo 1'de her iki elektrot için optimum kompozisyonlar verilmiştir.

Tablo 1. $\mathrm{Ca}$ ve $\mathrm{Mg}$ iyonofor ile hazırlanan elektrotların optimum membran bileşimleri

\begin{tabular}{lcccc}
\hline İSE (\%) & İyonofor & Plastiklestirici & PVC & KTpClPB \\
\hline $\begin{array}{l}\text { Ca membran } \\
\text { kokteyli }\end{array}$ & $2^{\text {a }}$ & $68^{\mathrm{b}}$ & 29 & 1 \\
$\begin{array}{l}\text { Mg membran } \\
\text { kokteyli }\end{array}$ & $1^{\mathrm{c}}$ & $63^{\mathrm{d}}$ & 33 & 0.74 \\
\hline
\end{tabular}

a: Ca iyonofor, b: NPOE, c: Mg iyonofor, d: [12,(4-etilfenil)dodesil)2 nitrofenil eter], İSE: İyon seçici elektrot, PVC: Polivinil klorür, KTPCIPB: Potasyumtetrakis (p-kloro) fenilborat, NPOE: Onitrofeniloktileter

\section{2. $\mathrm{Ca}^{2+}$-seçici PVC-membran elektrot}

Kalsiyum iyonofor; N,N-Dicyclohexyl-N',N'dioctadecyl-3-oxapentanamide $\quad\left(\mathrm{C}_{52} \mathrm{H}_{100} \mathrm{~N}_{2} \mathrm{O}_{3}\right)$ kullanılarak hazırlanan iyon-seçici PVC-membran elektrotun potansiyometrik davranışı, derişimi $10^{-1}$ $10^{-6} \mathrm{M}$ arasında değişen standart katyon $\left(\mathrm{Mg}^{2+}\right.$, $\mathrm{Ca}^{2+}, \mathrm{Li}^{+}, \mathrm{Na}^{+}, \mathrm{K}^{+}, \mathrm{NH}_{4}^{+}, \mathrm{Sr}^{2+}, \mathrm{Ba}^{2+}$ ) çözeltileri kullanılarak test edilmiştir. Hazırlanan $\mathrm{Ca}^{2+}$-seçici PVC-membran elektrotun Şekil 2'de gösterildiği gibi, diğer iyonlar yanında $\mathrm{Ca}^{2+}$ iyonuna karşı seçici olduğu, hızlı ve tekrarlanabilir cevap sergilediği gözlemlenmiştir.

\section{3. $\mathrm{Mg}^{2+}$-seçici PVC-membran elektrot}

Magnezyum iyonofor; 1,3,5-Tris[10- (1adamantyl)- 7,9-dioxo-6,10-diazaundecyl]benzene $\left(\mathrm{C}_{63} \mathrm{H}_{96} \mathrm{~N}_{6} \mathrm{O}_{6}\right)$ kullanılarak hazırlanan iyon-seçici PVC-membran elektrotun potansiyometrik davranışı, derișimi $10^{-1}-10^{-6} \mathrm{M}$ arasında değișen standart katyon $\mathrm{Mg}^{2+}, \mathrm{Ca}^{2+}, \mathrm{Li}^{+}, \mathrm{Na}^{+}, \mathrm{K}^{+}, \mathrm{NH}_{4}^{+}$, $\left.\mathrm{Sr}^{2+}, \mathrm{Ba}^{2+}\right)$ çözeltileri kullanılarak test edilmiştir. Hazırlanan $\mathrm{Mg}^{2+}$-seçici PVC-membran elektrotun Şekil 3'te gösterildiği gibi, diğer iyonlar yanında $\mathrm{Mg}^{2+}$ iyonuna karşı seçici olduğu, hızlı ve tekrarlanabilir cevap sergilediği gözlemlenmiştir. 


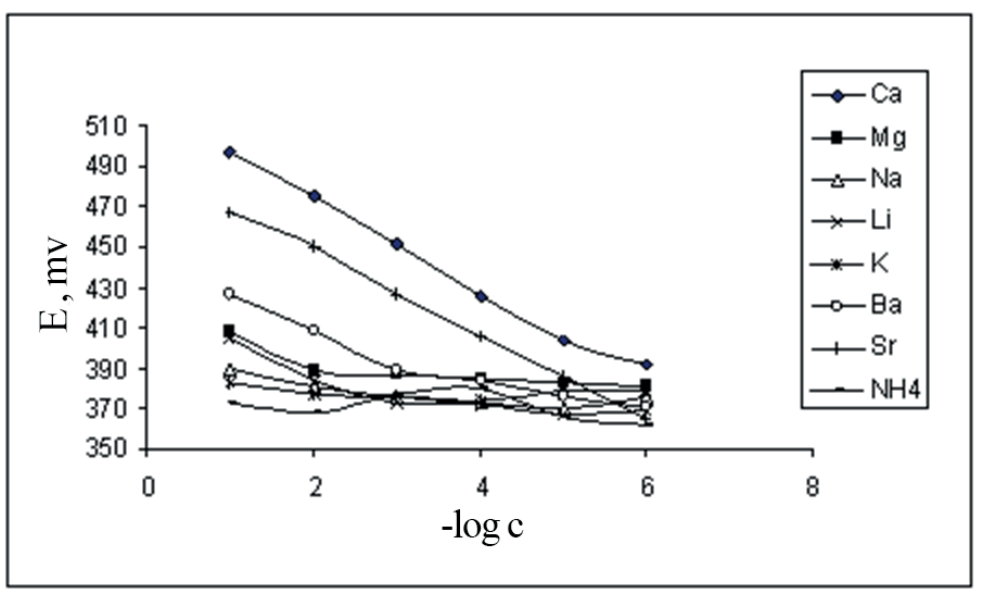

Şekil 2. $\mathrm{Ca}^{2+}$-seçici PVC-membran elektrotun farklı iyonlara karşı sergilediği potansiyometrik davranışı E: mV olarak potansiyel, c: mol L-1 olarak derişim, Ca: Kalsiyum, Mg: Magnezyum, Na: Sodyum, Li: Lityum, K: Potasyum, Ba: Baryum, Sr: Stronsiyum, $\mathrm{NH}_{4}$ : Amonyum

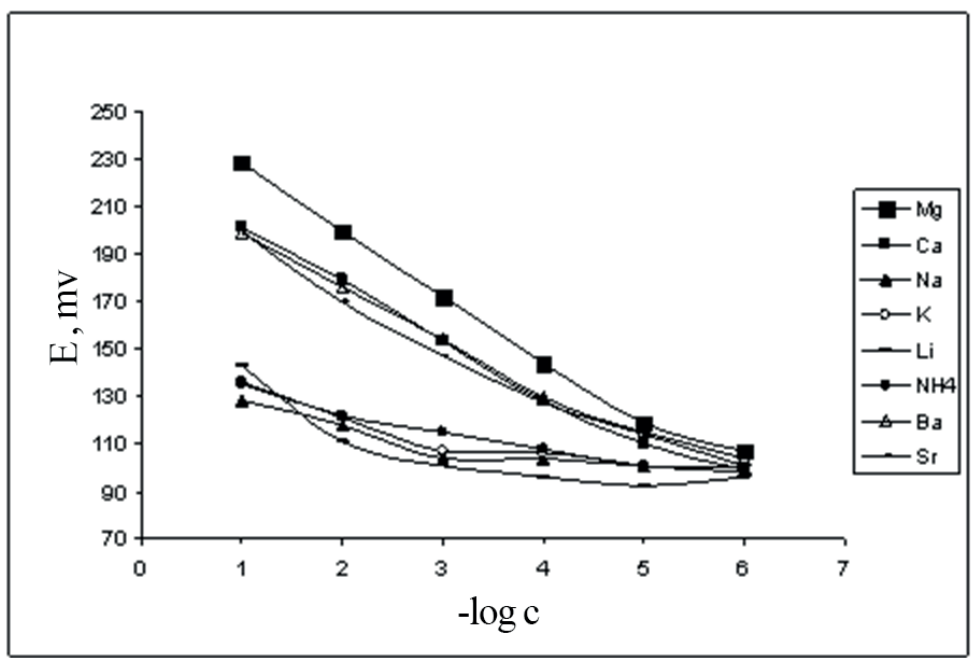

Şekil 3. $\mathrm{Mg}^{2+}$-seçici PVC-membran elektrotun farklı iyonlara karşı sergilediği potansiyometrik davranışı

\subsection{Cevap zamanı}

Şekil 4'te görüldüğü gibi elektrot, sırasıyla $10^{-1}-10^{-6} \quad \mathrm{M}$ standart kalsiyum çözeltilerine daldırılarak ölçümler alınmıştır. Derişimi $10^{-4} \mathrm{M}$ $\mathrm{Ca}^{2+}$ çözeltisinden $10^{-3} \mathrm{M} \mathrm{Ca}^{2+}$ çözeltisine geçişte elektrotun potansiyelinin dengeye gelme zamanının \% 95'ine karşılık gelen süre hesaplanarak cevap zamanı bulunmuştur. Cevap zamanı, $t_{95}<6 \mathrm{~s}$ olup çok kısadır (Grieken ve Bruin, 1994).

\section{5. pH çalışma aralığı}

Hazırlanan elektrotun pH çalışma aralığı pH's1 3-10 arasında değișen $10^{-3} \mathrm{M}$ ve $10^{-4} \mathrm{M}$ sabit $\mathrm{Ca}^{2+}$ miktarı içeren $5 \times 10^{-3} \mathrm{M}$ fosfat tamponu çözeltilerinde alınan ölçümlerle belirlenmiştir. Şekil 5'te görüldüğü gibi pH arttıkça sabit olması gereken potansiyel değerleri bir miktar azalmakta fakat $\mathrm{pH}=4-9$ aralığında elektrot ortam $\mathrm{pH}$ 'sından çok fazla etkilenmeden çalışabilmektedir. İlk olarak elektrot, $10^{-1}-10^{-6} \mathrm{M}$ standart $\mathrm{Ca}$ çözeltilerine daldırılarak kalibrasyon grafiği çizilmiş, daha sonra hazırlanan tampon çözeltilerinde ölçüm alınarak pH davranışı gözlemlenmiştir.

\subsection{Tekrarlanabilirlik}

Elektrot, $10^{-5}, 10^{-4}$, ve $10^{-3} \quad$ M'l $^{\prime} \mathrm{k} \quad \mathrm{Ca}$ çözeltilerine sırayla 24 defa daldırılmış ve her bir ölçümden sonra potansiyometrede yaklaşık aynı potansiyel değerleri okunmuştur. Şekil 6'da gösterildiği gibi elektrotun tekrarlanabilirliğinin çok iyi olduğu görülmüştür.

\subsection{Doğrusal çalışma aralığı ve tayin limiti}

Kalsiyum-seçici PVC-membran elektrodun doğrusal çalışma aralığı $10^{-1}$ ile $10^{-5} \mathrm{M}$ arasında değişmektedir (Şekil 7). Elektrot, bu konsantrasyonlar arasında doğrusal bir davranış göstermekte olup elde edilen doğrunun denklemi ve $\mathrm{R}^{2}$ değeri grafik üzerinde verilmektedir. Grafikten tayin limitinin $3.26 \times 10^{-6} \mathrm{M}$ olduğu hesaplanmıştır. 


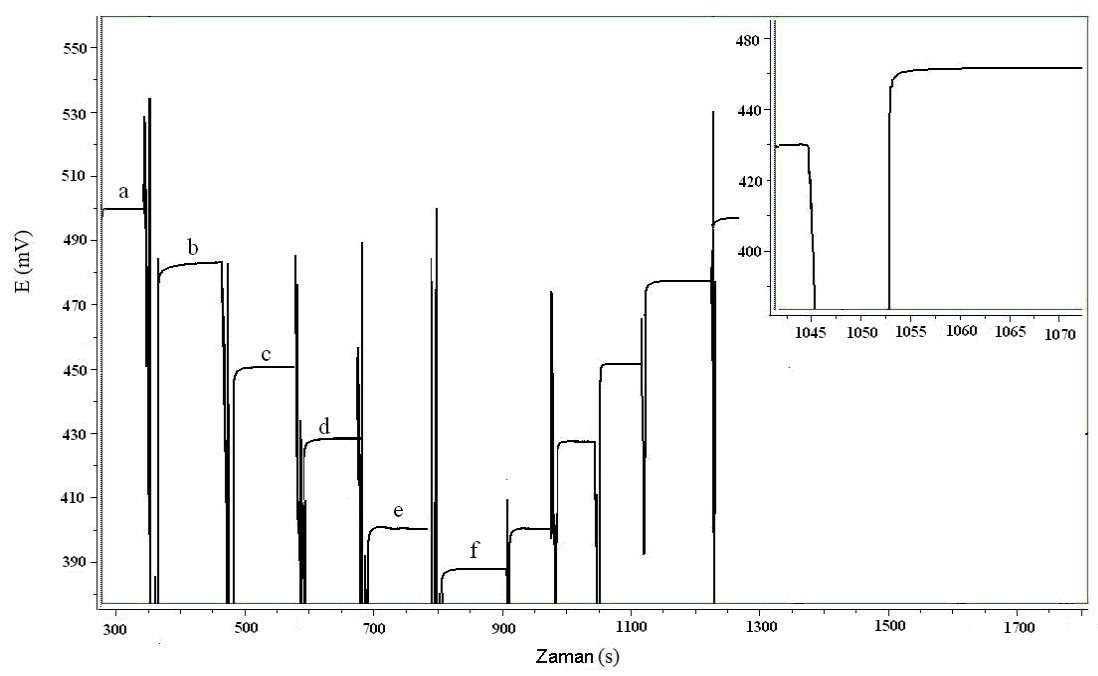

Şekil 4. $\mathrm{Ca}^{2+}$-seçici PVC-membran elektrotun cevap zamanı a: $1 \times 10^{-1} \mathrm{M}$, b: $1 \times 10^{-2} \mathrm{M}$, c: $1 \times 10^{-3} \mathrm{M}, \mathrm{d}: 1 \times 10 \mathrm{M}^{-4}$, e: $1 \times 10^{-5} \mathrm{M}$, f: $1 \times 10^{-6} \mathrm{M} \mathrm{Ca}^{2+}$ çözeltisi

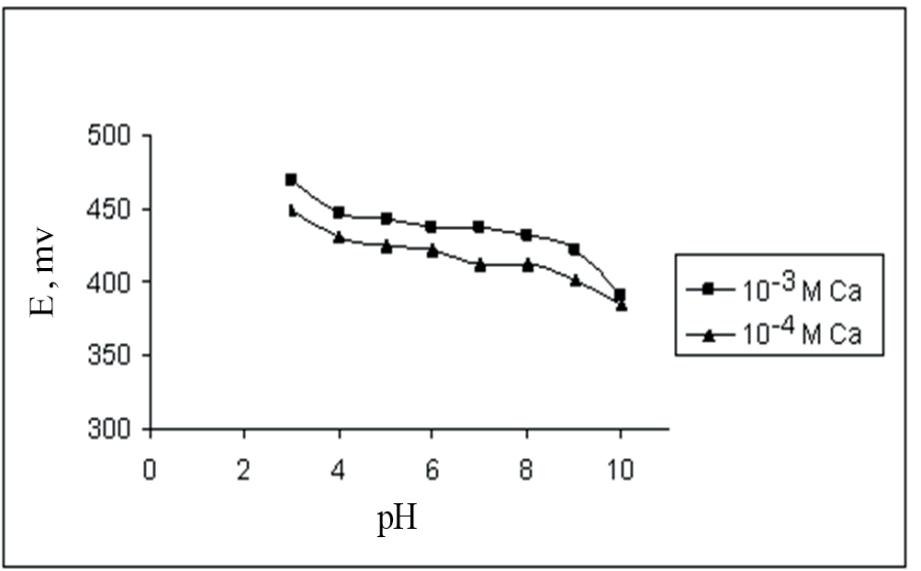

Şekil 5. $\mathrm{Ca}^{2+}$-seçici PVC-membran elektrotun $\mathrm{pH}$ çalışma aralı̆̆

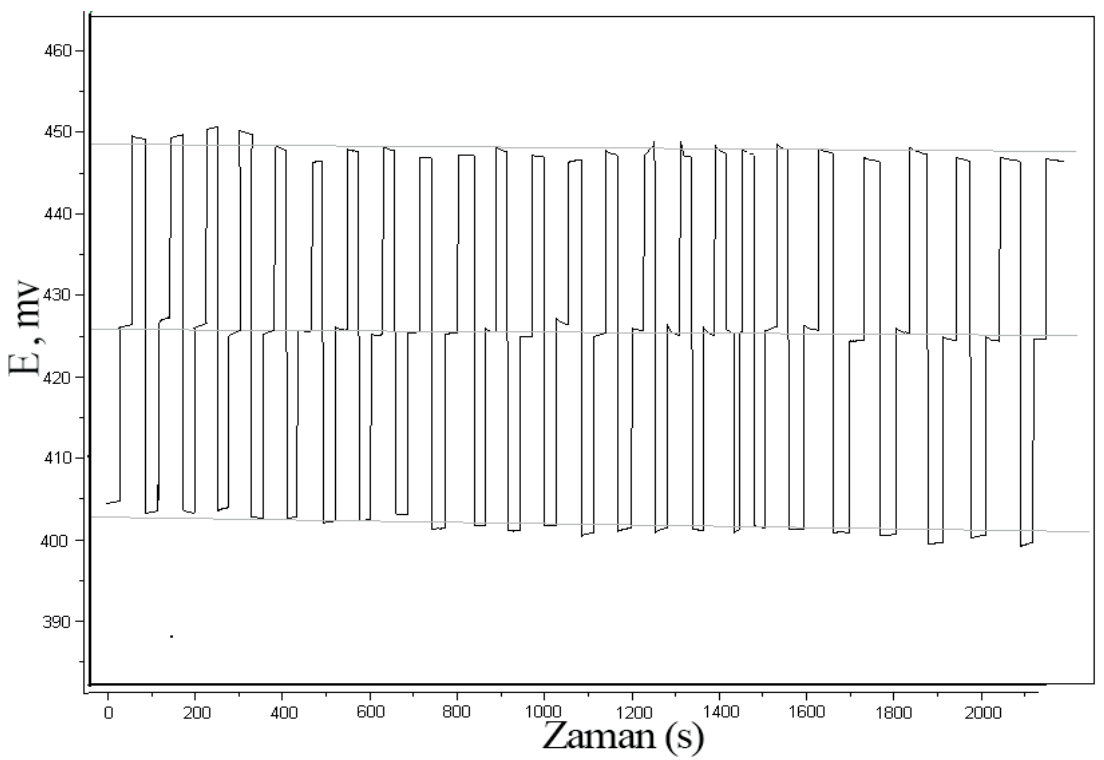

Şekil 6. $\mathrm{Ca}^{2+}$-seçici PVC-membran elektrotun tekrarlanabilirliği 


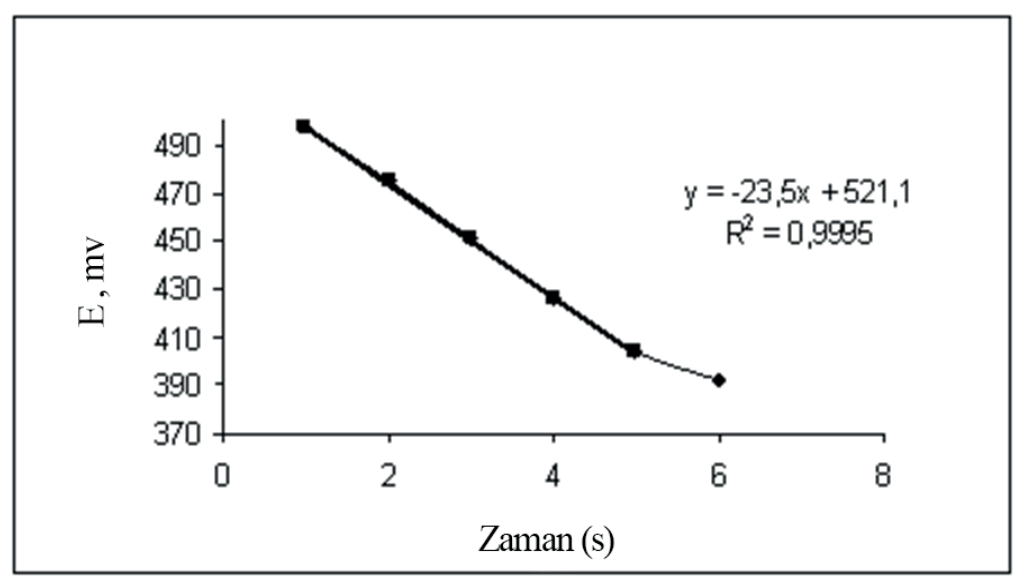

Şekil 7. $\mathrm{Ca}^{2+}$-seçici PVC-membran elektrotun doğrusal çalışma aralığ

Kalsiyum-seçici PVC-membran elektrot için görülen davranışlar laboratuvarda hazırlanan $\mathrm{Mg}^{2+}$ seçici PVC-membran elektrot için de gözlemlenmiştir. Kalsiyum ve magnezyum-seçici
PVC-membran elektrotların potansiyometrik performans özellikleri Tablo 2'de verilmiştir. Geliştirilen yöntemin doğruluğu, standart yöntem kabul edilen AAS yöntemi ile test edilmiştir. Bunun

Tablo 2. $\mathrm{Ca}^{2+}$ ve $\mathrm{Mg}^{2+}$-seçici PVC-membran elektrotların performans özellikleri

\begin{tabular}{|c|c|c|}
\hline Belirlenen elektrot özellikleri & $\mathrm{Ca}^{2+}$-seçici PVC-membran elektrot & $\begin{array}{l}\mathrm{Mg}^{2+} \text {-seçici PVC-membran } \\
\text { elektrot }\end{array}$ \\
\hline Çalışma aralığ $1 \mathrm{M})$ & $10^{-5}-10^{-1}$ & $10^{-5}-10^{-1}$ \\
\hline Tayin limiti & $3.26 \times 10^{-6}$ & $1.23 \times 10^{-5}$ \\
\hline Regresyon denklemi* ${ }^{*}$ & $y=23.5 x+521.1$ & $y=27.6 x+255.6$ \\
\hline $\mathrm{R}^{2 * *}$ & 0.9995 & 0.9993 \\
\hline Membran tipi & Kompozit membran & Kompozit membran \\
\hline pH çalışma aralığ 1 & $4-9$ & $4-10$ \\
\hline Seçicilik $^{* * *}$ & 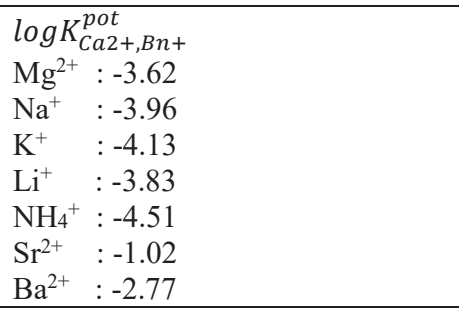 & $\begin{array}{l}\log K_{M g 2+, B n+}^{p o t} \\
\mathrm{Ca}^{2+}:-1.05 \\
\mathrm{Na}^{+}:-3.60 \\
\mathrm{~K}^{+}:-3.30 \\
\mathrm{Li}^{+}:-3.08 \\
\mathrm{NH}_{4}^{+}:-3.37 \\
\mathrm{Sr}^{2+}:-1.01 \\
\mathrm{Ba}^{2+}:-1.05\end{array}$ \\
\hline Cevap zamanı & $<6 \mathrm{~s}$ & $<10 \mathrm{~s}$ \\
\hline Potansiyel değişimi & $23.5 \mathrm{mV}$ & $27.6 \mathrm{mV}$ \\
\hline Elektrot kullanım ömrü & 8 hafta & 8 hafta \\
\hline
\end{tabular}

*: Burada y, E(mv); $\mathrm{x}$ ise $\mathrm{C}$ olarak gösterilen derişimi ifade etmektedir, ${ }^{* *}:$ Regresyon katsayısı, ${ }^{* * *}: K$, seçicilik katsayısı

için, elementlerin analizi için Photron Hallow Cathode Lambaları kullanılmıştır. Tablo 3'te analizde kullanılan dalga boyu, band geçiş aralığ1 ve lamba akım değerleri verilmiştir. Sistemde yakıcı gaz olarak hava/asetilen kullanılmıştır. Hazırlanan standart çözeltilerin absorbans ölçümlerinden $\mathrm{Ca}$ ve $\mathrm{Mg}$ iyonlarının kalibrasyon grafikleri çizilerek doğru denklemleri oluşturulmuştur. Daha sonra numunelerin absorbans değerleri okunarak içerisindeki Ca ve $\mathrm{Mg}$ miktarları ppm cinsinden bulunmuş ve Tablo 4'te verilmiştir.

Potansiyometrik performansları incelendiğinde hazırlanan her iki elektrotun $10^{-5}-10^{-1} \mathrm{M}$ aralığında
Nernstian cevap sergilediği görülmüștür. Elektrotların tayin limiti ve cevap süresi de oldukça iyidir. Gerçek örneklerle elektrotların ölçüm alınmasında ortamda bulunabilecek değişik iyonlara karşı göstermiş olduğu seçiciliğin birer ifadesi olan seçicilik katsayıları (Kij) ayrı çözelti metoduna göre hesaplanmıştır (Tablo 2).

Tablo 3. Analizde kullanılan dalga boyu, band geçiş aralığı ve lamba akım değerleri

\begin{tabular}{lccc}
\hline Element & $\begin{array}{c}\text { Kullanılan dalga } \\
\text { boyu (nm) }\end{array}$ & $\begin{array}{c}\text { Band geçis } \\
\text { aralığ } 1(\mathrm{~nm})\end{array}$ & $\begin{array}{c}\text { Lamba akım } \\
\text { değeri (mA) }\end{array}$ \\
\hline $\mathrm{Ca}$ & 422.7 & 0.5 & 6 \\
$\mathrm{Mg}$ & 285.2 & 0.5 & 4 \\
\hline
\end{tabular}


Tablo 4. Toprak numunelerinden elde edilen sonuçlar ${ }^{(1)}\left(\mathrm{mg} \mathrm{kg}^{-1}\right)$

\begin{tabular}{lccccc}
\hline \multirow{2}{*}{ Numune } & \multicolumn{2}{c}{ ISE ile bulunan sonuçlar } & \multicolumn{2}{c}{ AAS ile bulunan sonuçlar } & \multirow{2}{*}{$\mathrm{t}^{(2)}$} \\
\cline { 2 - 4 } & $\mathrm{Ca}^{2+}$ & $\mathrm{Mg}^{2+}$ & $\mathrm{Ca}$ & $\mathrm{Mg}$ & \\
Yol kenar1 tarla & $920 \pm 11$ & $321 \pm 22$ & $987 \pm 10$ & $355 \pm 12$ & 3.81 \\
Suni gübreli toprak & $1254 \pm 17$ & $517 \pm 13$ & $1317 \pm 13$ & $563 \pm 15$ & 3.79 \\
Hayvan gübreli toprak & $1015 \pm 13$ & $487 \pm 9$ & $1092 \pm 11$ & $513 \pm 9$ & 3.67 \\
\hline
\end{tabular}

${ }^{(1)}$ : Üç değerin ortalaması ve standart sapma, ${ }^{(2)}$ : Çift taraflı $\mathrm{t}$ testi $\left(\mathrm{GS}=\bar{x} \pm \frac{t S}{\sqrt{N}}, \% 95\right.$ güven aralığında)

Potansiyometrik duyarlılık, seçicilik, cevap zamanı, çalışma $\mathrm{pH}$ aralı̆̆ 1 , tekrarlanabilirlik ve elektrot ömrü açısından değerlendirildiğinde hazırlanan elektrotların toprak numunelerindeki $\mathrm{Ca}^{2+}$ ve $\mathrm{Mg}^{2+}$ tayini için başarı ile uygulanabileceğini göstermektedir.

\subsection{Uygulamalar}

Geliştirilen, bütünüyle katı hal-kontak iyonseçici PVC-membran elektrotlar, toprak örneklerindeki $\mathrm{Ca}^{2+}$ ve $\mathrm{Mg}^{2+}$ tayinlerinde kullanılmıştır. $\mathrm{Bu}$ amaçla, Samsun-Çarşamba bölgesinden üç farklı toprak çeşidi (yol kenarı tarla, suni gübreli toprak ve hayvan gübreli toprak) temin edilmiştir. Toprak numuneleri ilk önce havanda ögütüldü ve 24 saat etüvde $\left(110^{\circ} \mathrm{C}\right.$ 'de) kurutma işlemine tabi tutuldu. Daha sonra her numuneden 10 $\mathrm{g}$ alınarak $50 \mathrm{~mL}$ asetat tamponunda $\left(10^{-3} \mathrm{M}\right.$ HAc/NaAc, pH:4.50) çözüldü. Elde edilen çözelti süzülerek süzüntü kısımları alındı. Ölçümler numunelerin bu süzüntüleri kullanılarak gerçekleştirildi. Ayrıca standart $\mathrm{Ca}^{2+}$ ve $\mathrm{Mg}^{2+}$ çözeltileri de asetat tamponunda $\left(10^{-3} \mathrm{M}\right.$ HAc/NaAc, pH:4.50) hazırlanmıştır.

Kalsiyum ve $\mathrm{Mg}$ elementlerinin analizinde; fosfat, aluminat ve silikat gibi oksianyonlar cihazın cevabını azaltarak girișim oluştururlar. Bu etkiler, tüm çözeltilere bir serbestlestirici ajan $(0.1 \% \mathrm{~m} / \mathrm{V}$ lantan) eklenmesiyle veya yakıcı gaz olarak nitroz oksit/asetilen karıșımın kullanılmasıyla giderilebilir. Eğer yakıcı gaz olarak nitroz oksit/asetilen karışımı kullanılırsa bir iyonlaştırıcı tampon $(0.2 \% \mathrm{~m} / \mathrm{V}$ potasyum) gerekmektedir. Kalsiyum ve $\mathrm{Mg}$ elementlerinin analizinde tüm standart ve numune çözeltilerine $0.1 \% \mathrm{~m} / \mathrm{V}$ lantan eklenerek ölçümler alınmıştır (Anonymous, 1991).

Farklı toprak numunelerinin $\mathrm{Ca}$ ve $\mathrm{Mg}$ içerikleri hem iyon-seçici elektrotla (ISE) hem de standart metal tayin yöntemiyle belirlenmiştir. Ayrıca, geliştirilen yöntem için çift taraflı $\mathrm{t}$ testi denemesi yapılmış ve değerler 3.67-3.81 aralığında bulunmuştur. Bulunan bu değerler \% 95 güvenirlik düzeyinde verilen tablo değeri ile $\left(t_{\text {kritik }}=0.05\right)$ karşılaştırılmıştır. İstatistik tablosunda 2 serbestlik derecesi için $\mathrm{t}$ tablosunda verilen kritik değer 4.30'dur. Buna göre, bulunan t değerlerinin tümü verilen bu kritik değerden küçük olduğundan, geliştirilen $\mathrm{Ca}^{2+}$ ve $\mathrm{Mg}^{2+}$ tayin yöntemi ile standart yöntem arasında anlamlı bir şekilde fark bulunmadığını ve sonuçların birbiri ile uyumlu olduğunu göstermektedir.

\section{Sonuçlar}

Çalışmanın amacı kapsamında, ticari olarak satın alınan 2 farklı iyonofor madde kullanılarak toprak numunelerinde bulunan $\mathrm{Ca}$ ve $\mathrm{Mg}$ iyonlara duyarlı PVC-membran potansiyometrik iyon-seçici elektrotlar geliştirilmiştir. Hazırlanan bu elektrotların potansiyometrik performans karakteristikleri incelenmiş ve $\mathrm{Ca}^{2+}$ ve $\mathrm{Mg}^{2+}$-seçici PVC-membran elektrotlarla durgun ortamlarda direk ölçüm metodu ile bu iyonların gerçek numunelerdeki derişimleri hızlı, seçici ve tekrarlanabilir tayinleri başarı ile gerçekleştirilmiştir. Ayrıca, standart metal tayin yöntemi olan AAS tekniği kullanılarak da ölçümler alınmış ve sonuçlar karşılaştırmalı olarak verilmiştir. $\mathrm{Ca}^{2+}$ ve $\mathrm{Mg}^{2+}$-seçici PVC-membran elektrotlarla ile elde edilen değerler istatistiksel olarak değerlendirilmiş ve elde edilen sonuçlar arasında anlamlı bir fark bulunmamıştır. Geliștirilen mikro büyüklükteki bu sensörlere dayalı ölçüm yöntemi basit, kolay ve ekonomiktir. Geliştirilen bu elektrotlar ile toprak ve bitki numunelerindeki $\mathrm{Ca}^{2+}$ ve $\mathrm{Mg}^{2+}$ iyonlarının analizlerinin rutin olarak yapılabileceği ortaya konmuştur.

\section{Kaynaklar}

Alexandra, M.R.F., António, O.S.S.R., José, L.F.C.L., 1995. Flow injection systems with a stream splitting and a dialysis unit for the soil analysis of sodium and potassium by flame emission spectrometry, and calcium and magnesium by atomic absorption spectrophotometry. Communications in Soil Science and Plant Analysis, 26(1-2): 183-195.

Anonim, 2018. Toprak Verimlilik ve Bitki Besleme Yöntemi. (http://www.orfeteknik.com.tr/ortakutuphane4.htm), (Erişim tarihi: 19.02.2018).

Anonymous, 1991. Atomic Absorption Spectrometry Manual, Unicam Limited (Division of Analytical Technology Inc), York Street, Cambridge, Part IV, Section 27, 21.

Captian-Vallvey, L.F., Fernandez-Ramos, M.D., 2003. Characterization of a transparent optical test strip for quantification of water hardness. Analytica Chimica Acta, 481(1): 139-148.

Grieken, R.V., Bruin, M.D., 1994. Analytical chemistry division, commission on electroanalytical chemistry, 
recomendations for nomen-clature of ion-selective electrodes. Pure and Applied. Chemistry, 66(12): 2527-2536.

Güzel, N., Gülüt, K.Y., Büyük, G., 2004. Toprak Verimliliği ve Gübreler, Bitki Besin Elementlerine Giriş. Çukurova Üniversitesi Ziraat Fakültesi Genel Yayın No: 246, Ders Kitapları Yayın No: A-80, Adana, s. 323-329.

Işıldak, I., Asan, A., 1999. Simultaneous detection of monovalent anions and cations using all solid-state contact PVC membrane anion and cation-selective electrodes as detectors in single column ion chromatography. Talanta, 48(4): 967-978.

Kabrick, J.M., Goyne, K.W., Fan, Z.F., Meinert, D., 2011. Landscape determinants of exchangeable calcium and magnesium in ozark highland forest soils. Soil Science Society of America Journal, 75(1): 164-180.

Kantarc1, M.D., 1997. Kalsiyumun Bitki Beslenmesindeki Yeri ve Önemi. Çevre Korunmasında Kireç Kitabı, Boğaziçi Üniversitesi Yayınları No: 620, Boğaziçi Üniversitesi Matbaası, İstanbul.

Karaman, M.R., Aksu, A., Demirer, T., Er, F., 1999. Effect of potassium and magnesium fertilization on the growth, some nutrient status and $\mathrm{K}-\mathrm{Mg}$ uptake efficiency parameters of corn (Zea mays L.) grown on siltation soil. Journal of Agriculture, 18(13): $107-$ 116.
Koc, J., Szymczyk, S., 2003. Effect of agriculture intensity on the calcium and magnesium outflows from soils. Journal Elementology, 8(1): 231-238.

Lopez, G.I., Sanchez, M. M., Hernandez, C.M., 1996. Rapid flame AAS determination of $\mathrm{Fe}, \mathrm{Ca}$, and $\mathrm{Mg}$ in soils and sediments using slurries. Atomic Spectroscopy, 17(3): 107-111.

Pavel, N.N., 2001. Simultaneous separation and detection of anions and cations in ion chromatography. Trends in Analytical Chemistry, 20(6): 311-319.

Sang, H.H., Kang, S.L., Geun, S.C., Dong, L., Marek, T., 1993. Potentiometric detection in ion chromatography using multi-ionophore membrane electrodes. Journal of Chromatography A, 64(1): 283-288.

Watanabe, K., Tohda, K., Sugimoto, H., Eitoku, F., Inoue, H., Suzuki, K., Nakamura, S., 1991. Ionsensitive field effect transistor as a monovalent cation detector for ion chromatography and its application to the measurement of $\mathrm{Na}^{+}$and $\mathrm{K}^{+}$concentrations in serum. Journal of Chromatography, 566(1): 109-116.

Zhang, Y.G., Xiao, M., Dong, Y.H., Jiang, Y., 2012. Determination of soil exchangeable base cations by using atomic absorption spectrophotometer and extraction with ammonium acetate. Spectroscopy and Spectral Analysis, 32(8): 2242-2245.

Zikri, A., Julian, F.T., 1999. Determination of calcium, magnesium and strontium in soils by flow injection flame atomic absorption spectrometry, Talanta, 50(5): 929-937. 